\title{
What affects the arrogant, proud or ashamed pre-service teacher in mathematics? Effects of social comparison, gender and self-concept on self-conscious emotions
}

\author{
Lars Jenßen ${ }^{1}$ (1)
}

Received: 9 July 2020 / Accepted: 30 July 2021 / Published online: 30 August 2021

(C) The Author(s) 2021

\begin{abstract}
Emotions are essential for the development of professional competence and identity of pre-service teachers. Thus, they can also be seen as an inherent part of teachers' professional competence and identity. They also influence teachers' later emotional experience when teaching at school. Mathematics, especially, triggers activating emotions in pre-service primary school teachers. Pride and shame can be understood as relevant achievement emotions, which are also closely linked to the self-concept of a person. Nevertheless, they have been insufficiently studied among pre-service mathematics teachers so far. The present study examines authentic and hubristic pride and shame among $n=310$ German prospective primary school teachers in relation to self-concept (ability vs. effort), gender and social comparison with fellow students regarding their own achievement. On the one hand, the results point to the difference between authentic and hubristic pride, and on the other hand, the study provides evidence for the dynamic closeness of shame and hubristic pride. Practical implications, especially for teacher education, are discussed against the background of the limitations of the study.
\end{abstract}

Keywords Authentic pride $\cdot$ Hubristic pride $\cdot$ Ability $\cdot$ Effort $\cdot$ Mathematics $\cdot$ Preservice teachers

\section{Introduction}

Emotions play a significant role in educational processes. Emotions that are experienced in learning contexts and in relation to achievement are referred as achievement emotions (Pekrun \& Perry, 2014). In addition to the dimensions pleasant vs. unpleasant and activating vs. deactivating for the general categorization of emotions

Lars Jenßen

lars.jenssen@hu-berlin.de

1 Department of Educational Research, Humboldt-Universität zu Berlin, Unter den Linden 6, 10099 Berlin, Germany 
(Feldman Barrett \& Russell, 1998), achievement emotions are also described along the dimension process- vs. outcome-oriented (Pekrun \& Perry, 2014): Processorientated emotions, such as boredom, occur in learning situations and outcomeorientated emotions can be experienced prospectively (e.g., hope) or retrospectively (e.g., guilt) in relation to a specific achievement situation (e.g., an exam at university). In addition, emotion psychology also distinguishes between fundamental basic emotions (e.g., enjoyment, anxiety) and so-called self-conscious emotions (Lewis, 2003). Self-conscious emotions are strongly related to the self and its development (Lewis et al., 1989). From a developmental psychological perspective, a representation of the self is needed in order to experience self-conscious emotions such as pride or shame. In achievement situations, pride and shame seem to be self-referential, because success or failure are linked to internal attributions and these lead to experiences of pride or shame (Weiner, 1986).

In mathematics, emotions are assumed as domain-specific for learners (Goetz et al., 2006) as well as for teachers (Frenzel et al., 2015). Math-related beliefs or stereotypes (e.g., "Mathematics is an innate ability" or "Mathematics is not made for women") can promote mathematics specific emotional experiences (Goldin, 2014). In particular, a right-or-wrong orientation in mathematical learning and test situations can trigger activating achievement emotions such as shame (Bibby, 2002). However, it is not the nature of mathematics itself that causes the problem, but rather the way mathematics is conceptualized and taught (Jackson \& Leffingwell, 1999) and what has been experienced in mathematics during school or university (Brady \& Bowd, 2005). Didactic methods that are frequently used in mathematics, such as calculating at the blackboard, presentation of results and competitive games, promote social exposure and social comparison and thus trigger self-conscious emotions in particular (Jenßen et al., 2021b).

Emotions are especially important for the process of becoming a teacher through teacher education (Anttila et al., 2016). According to control-value theory (Pekrun \& Perry, 2014), emotions show reciprocal effects with knowledge through motivational processes. This also applies for pre-service teachers as they are also learners (Jenßen et al., 2021a). In many countries (e.g., Germany), primary teachers are usually trained as generalists (Cooke et al., 2019). As a result, they often have little mathematical knowledge and therefore often experience unpleasant emotions such as shame (Bibby, 1999, 2002).

However, emotions do not only affect competence development, they can also be conceptualized as inherent parts of professional competence of teachers (Blömeke et al., 2015). They influence their instructional practice and can be transferred to the students or influence students ' performance (Bieg et al., 2017; Frenzel, 2014; Frenzel et al., 2017). Emotions when teaching can be traced back in the individual learning history to the achievement emotions in the corresponding domain (Eren, 2014; Marbán et al., 2020; Olson \& Stoehr, 2019).

Emotions are also closely related to the teacher's identity (Timoštšuk \& Ugaste, 2012; Zembylas, 2003). Identity development takes place to a large extent during teacher education (Anttila et al., 2016). Self-conscious emotions are involved in this process to a large extent (Panagi, 2013), as they provide feedback on one' s own performance through continuous attributions (Weiner, 1986). Additionally, it has to be 
noted that self-conscious emotions, specifically, are highly important in social relationships. Emotions shape social relationships between teachers and their students (Clem et al., 2020; Mainhard et al., 2018).

Despite this theoretically assumed high importance of self-conscious emotions for pre-service primary teachers in mathematics, these have only been marginally investigated so far. Previous studies examined shame and pride together with other emotions on a more generalized level (Anttila et al., 2016) or investigated for example shame only qualitatively (Bibby, 2002; Panagi, 2013). However, specific factors affecting pre-service teachers' experiences of shame and pride in mathematics have been neglected so far.

\section{Self-conscious emotions}

\subsection{Shame}

Shame is an activating, unpleasant emotion that is experienced as intense and painful (Velotti et al., 2017). It is accompanied by global self-devaluating cognitions (e.g., "I am not right the way I am") (Velotti et al., 2017). On a behavioral level, shame expresses itself in the form of avoiding or enduring the shame-eliciting situation or overcompensating for subjectively perceived shortcomings (e.g., perfectionism, aggression) (Ashby et al., 2006; Bushman \& Baumeister, 1998; Tangney et al., 1992). Shame is experienced when failure is experienced (Russell \& McAuley, 1986) and this is attributed to global abilities (e.g., "I failed because I'm stupid.") (Tracy \& Robins, 2006). The interesting thing is that shame is also experienced by high achievers, who actually have a very high competence belief (Turner \& Schallert, 2001). Lewis (2003) argues that even minimal deviations from the idealself can elicit shame.

Shame is reported by prospective primary school teachers as not very frequent during the school years, but as domain-specific in mathematics (Jenßen et al., 2021a, 2021b): The majority of pre-service primary teachers has observed or experienced shameful situations in particular in mathematics. A large part of these shameful situations was initiated by the mathematics teacher at that time. Shame is also very rarely reported by student teachers during teacher education (Anttila et al., 2016). However, this may also be due to the fact that shame is reported less often just to avoid repeated shame experiences (de Hooge et al., 2011). Shame is often consciously perceived as only very fleeting, even if it can influence the behavior of a person for a longer time.

\subsection{Authentic and Hubristic Pride}

Pride was for a long time considered as the "neglected sibling of self-conscious emotions “ (Tangney, 1999, p. 557). Pride is experienced after success (Russell \& McAuley, 1986), for example solving a difficult task (Lewis et al., 1992) or accomplishing a relevant goal of identity development (Anttila et al., 2016; Tracy \& Robins, 2004). 
Pride is an activating achievement emotion that is experienced in educational situations retrospectively in relation to an outcome and which is closely linked to oneself (Oades-Sese et al., 2014). Pride is considered a performance-enhancing emotion, as it leads to a permanently increased motivation in achievement situations (Williams \& DeSteno, 2008). Tracy and Robins (2007) suggest two distinct facets, which show small positive correlations to each other (Liu et al., 2016; Tracy \& Robins, 2014): Authentic and hubristic pride. Both are experienced intraindividually as pleasant, but hubristic pride is regarded as a socially undesirable emotion.

Authentic pride is associated with terms like hard-working, achieving and successful (Tracy \& Prehn, 2012). It constitutes the affective core of the genuine selfesteem and is positively related to successful social relationships and is seen as a prosocial emotion (Tracy et al., 2009; Wubben et al., 2012). Authentic pride develops when success is attributed to effort (Tracy \& Robins, 2007). It is negatively related to shame (Tracy \& Robins, 2007).

Hubristic pride is perceived by others as arrogant (Tracy \& Prehn, 2012). It can also be understood as the dark side of pride. Hubristic pride represents the affective core of narcissistic self-aggrandizement and is positively related to antisocial behavior and impulsivity (Carver et al., 2010; Tracy et al., 2009). Compared to authentic pride, the hubristic type shows itself when success is attributed to one's own global ability (Tracy \& Robins, 2007). The interpersonal goals of hubristic pride are public recognition and dominance (Carver et al., 2010). A consequence of hubristic pride can be a lack of empathy and a blindness to the needs of others (Oades-Sese et al., 2014). As hubristic pride is sometimes conceptualized as a defence mechanism according to shame (e.g., resulting in a kind of narcissistic swinging between shame and hubristic pride in extreme cases of narcissism), a positive relationship between shame and hubristic pride is assumed (Tracy \& Robins, 2007).

In general, pride is reported as one of the most frequent emotions during pre-service teachers' education in mathematics and it also occurs frequently during teacher education across different situations (Anttila et al., 2016; Jenßen et al., 2021a, 2021b).

\subsection{Social and psychological factors affecting self-conscious emotions}

Self-conscious emotions develop over the life span and their development is closely related to factors of the social environment (Orth et al., 2010). Therefore, self-conscious emotions can also be referred as social emotions. The social context causes the experience of these emotions (van Osch et al., 2018).

One of the factors of the social environment can be the social comparison that a person undertakes. The more social comparisons between individuals regarding their achievement are fostered, the more shame and pride can be experienced by the individuals (Oades-Sese et al., 2014). For example, shame is often experienced due to social exposure (Smith et al., 2002). If the individual compares itself in a self-devaluating way (upward comparison), shame may be felt by the individual. As pride emotionally aims to ensure social status within a group or avoid social rejection (Oades-Sese et al., 2014), a downward comparison can be assumed as a causing 
factor. Studies reveal that children's specific intraindividual comparisons lead to a more authentically experienced pride (Gürel et al., 2019). When comparing one self's ability to others on a more global level, hubristic pride may be experienced.

Another factor shaped by the social environment is evident in gender differences regarding the experience of shame and pride. Studies indicate that shame is experienced more often by women than by men (Benetti-Mcquoid \& Bursik, 2005; Velotti et al., 2017). A meta-analysis reveals less gender differences for authentic and hubristic pride than for shame (Else-Quest et al., 2012). However, gender differences for adults regarding shame and authentic and hubristic pride depend on the specific domain (Else-Quest et al., 2012). For mathematics, it can be assumed that gender differences become evident in emotional experiences (Goldin, 2014). It can be stated that self-related beliefs and attributions are shaped specifically with respect to gender by the social environment of an individual in early life and that these seem to be stable over the life span (Felson \& Trudeau, 1991; Goldin, 2014; Ryckman \& Peckham, 1987). Studies on the gender-specific experience of shame and pride were conducted predominantly among children (Frenzel et al., 2007; Lewis et al., 1992; Stipek \& Gralinski, 1991). The study by Stipek and Gralinski (1991) examined the experience of pride and shame in relation to attributions of success and failure among students in mathematics. The results suggest that girls were more likely to attribute failure to their global ability, experience less pride after success and were less convinced that success can be achieved through effort. Girls also experience more shame and this can be observed in their behavior. Boys, on the other hand, attributed their successes more to their abilities. A person's gender seems to affect self-related competence beliefs and thus the emotional experience (Frenzel et al., 2007). As a result, girls tend to experience more shame and less pride than boys. Studies also show that parental (e.g., evaluative parenting style) and pedagogical factors (e.g., teaching style that postulates mathematics competence is an innate ability) can influence these self-related beliefs and attributions and promote experiences of shame and pride (Alessandri \& Lewis, 1993; Gunderson et al., 2012). In addition, females show more upward comparisons in academic settings than males (Pulford et al., 2018). This effect occurs especially in math-related domains.

In summary, it can be concluded that a complex of self-related beliefs and assumptions about oneself and especially about one's own competence is affected by the social environment (Kurtz-Costes \& Schneider, 1994; Lohbeck et al., 2017). It could affect the belief system for example through specific attributions fostered by teachers or parents (Rytkönen et al., 2007). This cognitive system can be conceptualized as a person's self-concept (Gecas, 1982). It is understood as a stable selfreferential construct that is defined as "a product of a self-reflexive activity" (Gecas, 1982, p.3). Similar to emotions, the self-concept is assumed as domain-specific (Marsh, 1990). As mentioned before, a relation between the ability self-concept and shame and hubristic pride on the one hand, and a relation between the effort selfconcept and authentic pride on the other hand, can be assumed (Tracy \& Robins, 2007). In general, studies reveal a reciprocal relationship between self-concept and achievement emotions in mathematics, with empirical evidence for a stronger effect of self-concept on emotion (Ahmed et al., 2012). The authors of this study state, that prior experiences form a stable self-schema which leads to specific emotions in 
mathematics and that this may be the explanation of the stronger effect from selfconcept to emotion.

\section{Research question and hypotheses}

The present study aims to contribute to the investigation of self-conscious emotions in education, especially among pre-service mathematics teachers, by studying the effects of variables that affect the experience of self-conscious emotions. The research question of the study is to what extent do facets of self-concept (ability vs. effort), gender and social comparison affect the experience of authentic and hubristic pride and shame among pre-service primary school teachers in mathematics? On the basis of theoretical ideas and empirical findings, which have already been mentioned above, the following hypotheses are formulated:

According to the findings of Tracy and Robins (2007) and Liu et al. (2016) it is assumed that authentic and hubristic pride are weakly positively associated (H1a), authentic pride and shame are negatively related and hubristic pride is positively related with shame $(\mathrm{H} 1 \mathrm{~b})$.

Against the background of theories on attribution and self-concepts, it is assumed that the experience of authentic pride among pre-service primary school teachers in mathematics is affected by the effort self-concept (H2a). In contrast, their experience of hubristic pride and shame is affected by their ability self-concept (H2b).

In addition, it is assumed that female pre-service teachers feel less authentic and hubristic pride $(\mathrm{H} 3 \mathrm{a})$ and are more ashamed than male pre-service teachers $(\mathrm{H} 3 \mathrm{~b})$. In accordance to studies on the relevance of gender for individuals' self-concept, it is further assumed that gender also affects both self-concept facets $(\mathrm{H} 3 \mathrm{c})$.

For the effects of the social comparison it is assumed that it causes the experience of shame and hubristic and authentic pride in a different way. The more the pre-service teachers rate their mathematical competences as above the average compared to others (downward comparison), the more authentic and hubristic pride and the less shame they experience ( $\mathrm{H} 4 \mathrm{a})$. Based on the assumption that hubristic pride is crucial for the maintenance of social dominance, it is hypothesized that this effect is much stronger compared to the effect on authentic pride. It is also assumed that gender has an effect on social comparison, with females making less downward comparisons (H4b). Figure 1 summarizes the theoretically assumed relationships.

\section{Method}

\subsection{Participants}

The study was conducted with $n=310$ pre-service primary school teachers from Germany. The majority of the participants was female $(82.9 \%$ female, $17.1 \%$ male). The mean age of the participants was $M=28.2$ years $(S D=8.0)$. The participants were on average in the $M=3.81$ semester $(S D=2.41 ; \operatorname{Min}=1, \operatorname{Max}=15)$. The majority of the students were in their bachelor's degree $(65 \%)$ and about one third 


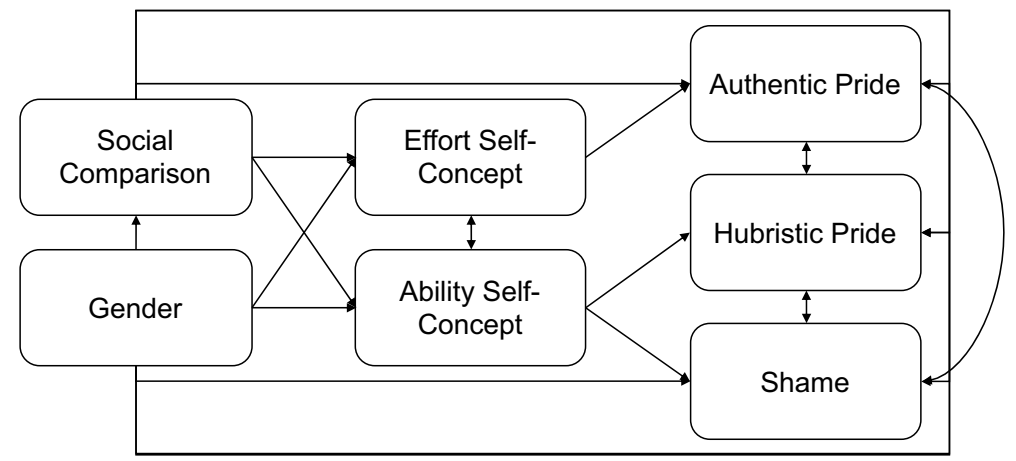

Fig. 1 Theoretical model

were in their master's degree (35\%). Teachers in Germany are trained as generalists, whereby mathematics is usually part of the curriculum alongside two other subjects. All participants had already attended courses in mathematics (content-related as well as didactics-related). Data collection was carried out online during the semester. The pre-service primary school teachers received no incentives for their participation.

\subsection{Instruments}

To assess pre-service primary teachers' authentic and hubristic pride in mathematics, two distinct subscales of the Pride in Mathematics Questionnaire (PriMa-Q) (Jenßen, 2020a) was used. The scale concerning authentic pride captures five items (e.g., "When I have mastered a challenge in math, I am proud of it.") that have to be rated on a 5-point scale ranging from 0 (=does not apply) to 4 (=fully applies). The second scale captures hubristic pride in mathematics by four items (e.g., "I am proud that I seem to have special mathematical abilities."). The items have also to be rated on a 5-point scale ranging from 0 (=does not apply) to 4 (=fully applies). PriMa- $Q$ assesses the experience of both pride facets on a trait level.

Pre-service primary teachers ' shame in mathematics was assessed by the Shame in Mathematics Questionnaire (SHAME-Q) (Jenßen, 2020b). The questionnaire consists of six items (e.g., "I am ashamed that I am not as good in math as I would like to be.") that have to be rated on a 5-point scale ranging from 0 (=does not apply) to 4 (=fully applies). The questionnaire can be seen as valid with respect to content, factorial structure and relations to other variables.

The participants' ability self-concept and the effort self-concept in mathematics were assessed by applying two subscales of the SELF-Questionnaire developed by Roesken et al. (2011). The ability scale captures five items that have to be rated on a 5-point scale ranging from 1 (=does not apply) to 5 (=fully applies). The scale consists of some reversed items (e.g., "I am not good in math.") which have to be inverted, so higher scores imply a higher ability self-concept. The effort scale is a short scale with three items (e.g., "I have worked hard to learn math."). The items have to be evaluated on the same scale as the items concerning the 
ability self-concept. Both scales have to be validated regarding structure and content (Roesken et al., 2011).

The social comparison was operationalized by the question "How do you rate your mathematical competence compared to your fellow students?". Participants were asked to rate this question from 0 (=below average) to 4 (=above average) where 2 represents a balanced category (=average). High values on this variable indicate a downward comparison and low values indicate an upward comparison.

\subsection{Data analysis}

The hypothesized relations between the variables were analyzed by applying structural equation modeling. The maximum likelihood estimator with robust standard errors (MLR) was applied to ensure an adequate estimation of the standard errors due to non-normal distributions of indicators and the sample size below $n=400$ (Rhemtulla et al., 2012). In a first step, one confirmatory factor analysis (CFA) model per construct was defined and analyzed. Items were used as indicators for the latent factor. Correlations between residuals were allowed. In a second step, the models were integrated into a complex model and the assumed relationships (Fig. 1) were examined for significance and effect size. All possible indirect effects were also examined. Common fit criteria were used to evaluate the model fit ( $\mathrm{Hu} \&$ Bentler, 1999). All analyses were carried out by using Mplus 8 (Muthén \& Muthén, 2017).

\section{Results}

The descriptive results of the variables used are given in Table 1. Participants indicated on average a high experience of authentic pride and a low level of hubristic pride measured by the used scales. The experience of shame also seems to be at a low level on average by taking into consideration the theoretically possible range. The levels of the self-concepts seem to be above the theoretically assumed average. On average, participants indicated a more downward comparison.

In a first step, one CFA model per each construct was modelled. All factor loadings across all specified models were significant $(p<0.001)$ and substantial $(\lambda>0.3)$. For authentic pride, the defined model fitted the data well $\left(\chi^{2}(5)=9.43\right.$, $p=0.09$, RMSEA $=0.05[0.00 ; 0.11] \mathrm{CFI}=0.99, \mathrm{SRMR}=0.02)$. Reliability was also good (McDonald's $\omega=0.89$ ). The separate model for hubristic pride had an excellent fit to the data $\left(\chi^{2}(2)=1.67, p=0.43\right.$, RMSEA $=0.00[0.00$; 0.11 , CFI $=1.00$, SRMR=0.01). Reliability of the scale was good (McDonald's $\omega=0.87)$. The separate model for shame also showed a good model fit $\left(\chi^{2}(7)=15.49, p=0.03, \mathrm{RMSEA}=0.06[0.01 ; 0.11] \mathrm{CFI}=0.99, \mathrm{SRMR}=0.02\right)$ and the reliability was high (McDonald's $\omega=0.92)$. For the ability self-concept, the model fitted the data also very $\operatorname{good}\left(\chi^{2}(3)=1.26, p=0.74, \mathrm{RMSEA}=0.00\right.$ $[0.00 ; 0.07] \mathrm{CFI}=1.00, \mathrm{SRMR}=0.01)$ with a good reliability of the latent factor (McDonald's $\omega=0.87$ ). For the effort self-concept, the model was saturated due 


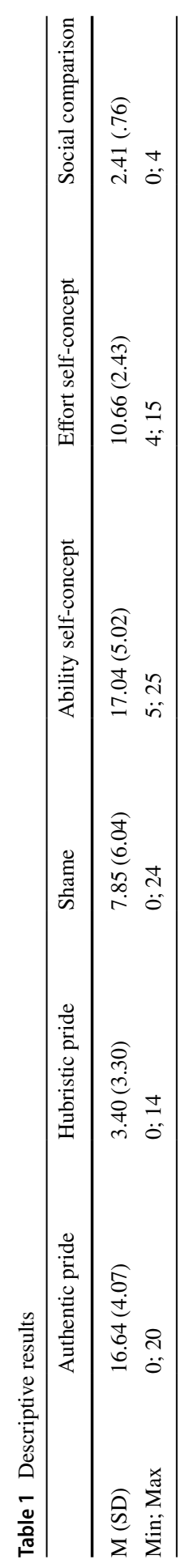


Table 2 Latent correlations between latent variables

Authentic pride

Hubristic pride

Shame

Ability

self-

concept

\begin{tabular}{lllll} 
Hubristic pride & .27 & -.43 & \\
Shame & - & .68 & -.75 & - \\
Ability self-concept & - & - & - & - \\
Effort self-concept & .25 & & \\
\hline
\end{tabular}

Only significant correlations are presented $(p>.001)$

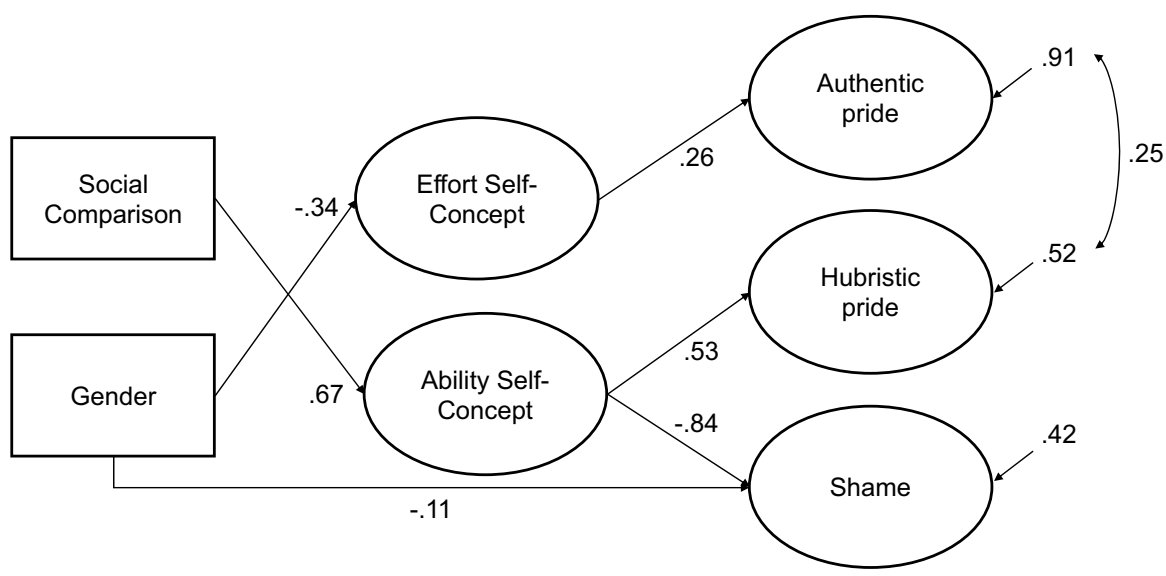

Fig. 2 Empirical model (significant standardized coefficients are presented, $p<.001$ )

to the limited number of three indicators. The reliability was good (McDonald's $\omega=0.71$ ). Latent correlations between latent variables are given in Table 2.

In a second step, the separate models as well as the manifest variables (gender, social comparison) were integrated in a complex model. The fit of the model was acceptable $\left(\chi^{2}(252)=447.81, p<0.001\right.$, RMSEA $=0.05[0.04 ; 0.05]$ CFI $=0.95$, SRMR =0.06). Results of this model for the standardized solution are shown in Fig. 2. Results of the unstandardized solution are given in the Appendix.

In the present application, the results show that authentic and hubristic pride also appear as distinct constructs. There is a small positive correlation between the two emotions (H1a). However, authentic pride showed no significant relation to shame ( $r_{\text {authentic,shame }}=-0.14, p=0.08$ ), while hubristic pride and shame were significantly associated with each other (H1b). The effort self-concept and the ability self-concept also appeared as two distinct facets. However, there was no significant relation between them ( $\left.r_{\text {effort,ability }}=-0.10, p=0.22\right)$.

As theoretically assumed, authentic pride was positively affected by the effort self-concept (H2a), and shame and hubristic pride were positively affected by the ability self-concept (H2b) in the full model. The effects are in line with theoretical 
assumptions (negative for shame, positive for hubristic pride). The effects of the ability self-concept were stronger than those of the effort self-concept.

There were no significant direct effects of gender on authentic and hubristic pride $\left(\beta_{\text {authentic }}=-0.02, p=0.74 ; \beta_{\text {hubristic }}=0.03, p=0.64\right)(\mathrm{H} 3 \mathrm{a})$. However, gender had a direct negative effect on the experience of shame $(\mathrm{H} 3 \mathrm{~b})$. According to this, male participants experienced less shame than female participants. The effect was small. Partially contrary to the hypotheses, direct effects of gender on the facets of the selfconcept were not generally found $(\mathrm{H} 3 \mathrm{c})$. There were no significant effects of gender on the ability self-concept ( $\beta=0.06, p=0.38$ ). However, a negative effect of gender on effort self-concept was shown. This means that male participants conceptualized themselves less in terms of effort than female participants.

The ability self-concept increases the more individuals consider their competence to be higher in comparison to fellow students (downward comparison). The effort self-concept was independent of the social comparison $(\beta=0.10, p=0.45)$. There were no significant direct effects of the social comparison on the self-conscious emotions (H4a). ( $\beta_{\text {authentic }}=-0.04, p=0.86 ; \beta_{\text {hubristic }}=0.21, p=0.14 ; \beta_{\text {shame }}=0.15$, $p=0.28$. No effect of gender on social comparison was found $(\beta=0.12, p=0.14)$ (H4b).

The significant indirect effects are reported below: The more the participants rated their competence higher in comparison to their fellow students (downward comparison), the stronger the hubristic pride is reported, mediated through the ability self-concept $\left(\beta_{\text {ind } 1}=0.36, p<0.001\right)$. However, the indirect effect of the social comparison, mediated by the ability self-concept, on shame was $\beta_{\text {ind } 2}=-0.56$ $(p<0.001)$. The lower the participants considered their competence compared to their fellow students (upward comparison), the more shame they reported. Gender showed an indirect effect of $\beta_{\text {ind } 3}=-0.10(p<0.05)$ on the experience of authentic pride, mediated through the effort self-concept. This means that male participants experience less authentic pride than female participants when taking the effort selfconcept into account. There were no further significant indirect effects found.

To validate the stability of the suggested model across different stages of teacher education, participants' semester was included as a control variable $\left(\chi^{2}(270)=475.79, \quad p<0.001, \quad\right.$ RMSEA $=0.05 \quad[0.04 ; 0.06], \quad \mathrm{CFI}=0.95$, SRMR $=0.06$ ). No significant effects of this variable were found and estimations of the analyzed coefficients did not differ in both models.

\section{Discussion}

This study has examined shame and pride and the constructs that affect them in preservice primary school teachers in mathematics. According to the model of Tracy and Robins (2007), pre-service teachers' pride in mathematics was distinguished for the first time between authentic and hubristic pride. The results of the study suggest that pre-service primary teachers experience more authentic than hubristic pride in mathematics. However, it should be noted that these constructs were measured by self-reports. Hubristic pride is subjectively rarely rated as high (Liu et al., 2016), which could be due to the subjectively perceived social undesirability of this 
emotion (Tracy \& Prehn, 2012). Consequently, hubristic pride is rated higher by strangers (Liu et al., 2016). Similar effects are shown for shame: Shame is often felt only temporarily and is reluctantly reported, since the subjective risk of repeated feelings of shame can increase (de Hooge et al., 2018).

In contrast to the hypothesis that shame is negatively associated with authentic pride and positively associated with hubristic pride, no significant relations were found between shame and authentic pride but a negative one between shame and hubristic pride in the present study. This may also have something to do with the assessment method of the constructs by using self-reports. The assumed positive relationship between hubristic pride and shame may make sense conceptually, but may not be consciously apparent to individuals. In addition, authentic pride is based more on individual achievement experiences and less on the general ability. Therefore, the experience of authentic pride and the experience of shame may be independent. In line with the theory and previous empirical evidence, a small positive correlation between hubristic pride and authentic pride were found (Liu et al., 2016). The experience of both emotions also goes beyond the cognitive representation in terms of self-concept. The findings can be understood as an empirical validation of the model of Tracy and Robins (2007) in educational contexts. The distinction between authentic and hubristic pride also makes sense in the present study, since both emotions show different relation patterns to other constructs. In particular the differential effects of ability self-concept and effort self-concept appear to be important in this context.

The way in which a pre-service primary school teacher compares his or her competence in mathematics with that of his or her fellow students is relevant whether the teacher experiences hubristic pride or shame. However, pre-service primary teachers' experience of authentic pride in mathematics was not affected by this social comparison. In light of this, hubristic pride can possibly also be understood as the social side of pride compared to authentic pride. However, this social aspect could have unpleasant effects. The emotional costs of this social comparison might be high. Either the pre-service teachers themselves experience unpleasant emotions such as shame, although this relationship seemed to be not empirically present in the study, or others experience them through devaluation due to the pre-service teachers' hubristic pride. Mathematics anxiety has already been conceptualized as such an emotional cost factor among pre-service primary school teachers (GonzalezDeHass et al., 2017). Maybe shame (individual) and hubristic pride (interpersonal) also represent these emotional costs in mathematics. The intraindividual comparison of achievement in mathematics may be more functional for pre-service teachers (Gürel et al., 2019), as it can initiate achievement behavior (Williams \& DeSteno, 2008). Authentic pride can be understood as emotional information that leads to an adaption of the achievement behavior (Weidman et al., 2016).

Findings also revealed no gender effects on the ability self-concept, but on the effort self-concept. These results were contrary to the hypotheses. It turned out that the effort self-concept was more strongly associated with females. This finding could be the result of specificities of the sample or selection effects before teacher education. It is possible that female students have learned in the past that they must make an effort in mathematics. However, it may also be that only 
those female pupils decide to become primary school teachers or to take mathematics as a subject of study who conceptualize their self in mathematics more in terms of effort. Most of the studies on the relation of gender and mathematics deal with pupils and not with university students or (pre-service) teachers. Studies also show that gender effects are less stable and can change over time due to societal processes (Lindberg et al., 2010). However, the present study revealed, that female pre-service teachers experienced more authentic pride, but also more shame. The effect of gender on shame is not mediated by the self-concept (neither effort nor ability). The effect may be caused by a general self-concept that is not specific to mathematics. For females, it is reported that in general, i.e. across different domains, they are more likely to experience shame than males (ElseQuest et al., 2012).

The present study shows that social comparison, self-concept and gender might be relevant variables that can affect pre-service primary teachers' experiences of self-conscious emotions in mathematics. Accordingly, the results have practical implications, especially for primary teacher education in mathematics. When achievement in mathematics is related to global ability, the experience of hubristic pride and shame can increase. Against the background of the present findings, it seems to make more sense to associate achievement in mathematics with effort in order to promote the effort self-concept. Therefore, achievement should be associated with specific effort ("You did it because you learned") and not with global ability ("You are a good student in general"). Gender effects should also be considered. Male pre-service teachers should be made more aware of their specific achievements than of their global abilities. In addition, social comparisons should be avoided. For instance, this means that this is not done communicatively ("You are the best of all anyway"), nor didactically (e.g., through competitive games or public evaluations that imply social comparisons). Otherwise, pre-service teachers may be tempted to arrogant behavior when experiencing success or to shameful experiences when failing. Both consequences would be difficult to regulate individually. A special aspect of the implications of the results is also important in view of the population. Pre-service teachers are not only learners, but later also educators and thus, social models for their students. Therefore, it may be useful for pre-service teachers to reflect on their self-conscious emotions in mathematics and to be aware of the relationship with self-concept, social comparison and gender. This may have consequences for their instructional behavior and their competence to create an emotionally pleasant atmosphere in mathematics. Against the background of the present study, relevant follow-up questions mainly concern the educational consequences of pre-service primary teachers ' experiences of shame and authentic and hubristic pride. These could concern for example performance or epistemic beliefs (e.g., mathematical competences are stable or innate), which in turn result in different instructional behavior. The social component of self-conscious emotions, which can manifest itself both in the instruction and in the relationship with the students, seems particularly important. 


\section{Limitations}

Nevertheless, the results of the present study and thus also the implications are only to be understood as indications against the background of limitations of the study. First, the sample size is small, which makes the use of an MLR-estimator necessary. The sample size is also reflected in the acceptable model fit of the complex model. Moreover, the study represents a cross-sectional design which does not allow causal conclusions to be drawn. However, it should be noted that the results were stable even under the control of the number of semesters completed by the participants. All participants were from Germany. Teacher education of primary school teachers in Germany takes rather place at a general level and is largely organized on an interdisciplinary basis. However, mathematics is usually a compulsory subject at university for pre-service teachers. This is also the case in many other countries. The scales used are short, but provide an economic assessment of the constructs. Comprehensive validation studies are available for the scales (e.g., Jenßen, 2020a, 2020b; Roesken et al., 2011).

\section{Conclusions}

The present study gives insight in relations between pre-service primary teachers' achievement emotions, self-concepts by taken social comparisons and gender effects into account. It also highlights the importance of going beyond anxiety and enjoyment as pre-service teachers' achievement emotions as self-conscious emotions such as shame as well as authentic and hubristic pride might be relevant parts of their later identities. When examining these emotions, it becomes clear that social comparisons might have negative effects in terms of shameful experiences or arrogant feelings. Avoiding these social comparisons and establishing an effort self-concept might be a fruitful strategy to foster pre-service teachers' experiences of authentic pride. The present study is a first step towards a systematic investigation of shame and authentic and hubristic pride in mathematics.

\section{Appendix: Unstandardized solution}

\begin{tabular}{lcc}
\hline Effects & Estimated coefficient & $p$-Value \\
\hline authentic pride with hubristic pride & 0.03 & 0.02 \\
authentic pride with shame & -0.03 & 0.50 \\
hubristic pride with shame & 0.01 & 0.10 \\
ability self-concept on authentic pride & 0.18 & 0.29 \\
ability self-concept on hubristic pride & 0.14 & $<0.001$ \\
ability self-concept on shame & -0.94 & $<0.001$ \\
effort self-concept on authentic pride & 0.32 & $<0.001$ \\
effort self-concept on hubristic pride & 0.01 & 0.77 \\
\hline
\end{tabular}




\begin{tabular}{lcc}
\hline Effects & Estimated coefficient & $p$-Value \\
\hline effort self-concept on shame & -0.10 & 0.28 \\
ability self-concept with effort self-concept & -0.06 & 0.20 \\
social comparison on ability self-concept & 0.71 & $<0.001$ \\
social comparison on effort self-concept & 0.08 & 0.45 \\
gender on ability self-concept & 0.12 & 0.38 \\
gender on effort self-concept & -0.57 & $<0.001$ \\
gender on social comparison & 0.25 & 0.16 \\
\hline
\end{tabular}

Funding Open Access funding enabled and organized by Projekt DEAL. This research did not receive any specific grant from funding agencies in the public, commercial, or not-for-profit sectors.

Availability of data and material Not applicable.

Code availability Not applicable.

Availability of data and material Not applicable.

Code availability Not applicable.

Availability of data and material Not applicable.

Code availability Not applicable.

\section{Declarations}

Conflict of interest Author declare that they have no conflict of interest.

Informed consent Informed consent was obtained from all individual participants included in the study.

Ethical approval All procedures performed in studies involving human participants were in accordance with the ethical standards of the institutional and/or national research committee and with the $1964 \mathrm{Hel}-$ sinki declaration and its later amendments or comparable ethical standards.

Open Access This article is licensed under a Creative Commons Attribution 4.0 International License, which permits use, sharing, adaptation, distribution and reproduction in any medium or format, as long as you give appropriate credit to the original author(s) and the source, provide a link to the Creative Commons licence, and indicate if changes were made. The images or other third party material in this article are included in the article's Creative Commons licence, unless indicated otherwise in a credit line to the material. If material is not included in the article's Creative Commons licence and your intended use is not permitted by statutory regulation or exceeds the permitted use, you will need to obtain permission directly from the copyright holder. To view a copy of this licence, visit http://creativecommons.org/licen ses/by/4.0/. 


\section{References}

Ahmed, W., Minnaert, A., Kuyper, H., \& van der Werf, G. (2012). Reciprocal relationships between math self-concept and math anxiety. Learning and Individual Differences, 22(3), 385-389. https://doi.org/10.1016/j.lindif.2011.12.004

Alessandri, S. M., \& Lewis, M. (1993). Parental evaluation and its relation to shame and pride in young children. Sex Roles, 29(5/6), 335-343.

Anttila, H., Pyhältö, K., Soini, T., \& Pietarinen, J. (2016). How does it feel to become a teacher? Emotions in teacher education. Social Psychology of Education, 19(3), 451-473. https://doi.org/ 10.1007/s11218-016-9335-0

Ashby, J. S., Rice, K. G., \& Martin, J. L. (2006). Perfectionism, shame, and depressive symptoms. Journal of Counseling and Development, 84, 148-156.

Benetti-Mcquoid, J., \& Bursik, K. (2005). Individual differences in experiences of and responses to guilt and shame: Examining the lenses of gender and gender role. Sex Roles, 53(1-2), 133-142. https:// doi.org/10.1007/s11199-005-4287-4

Bibby, T. (1999). Subject knowledge, personal history and professional change. Teacher Development, 3(2), 219-232. https://doi.org/10.1080/13664539900200084

Bibby, T. (2002). Shame: An emotional response to doing mathematics as an adult and a teacher. British Educational Research Journal, 28(5), 705-721. https://doi.org/10.1080/0141192022000015543

Bieg, M., Goetz, T., Sticca, F., Brunner, E., Becker, E., Morger, V., \& Hubbard, K. (2017). Teaching methods and their impact on students' emotions in mathematics: An experience-sampling approach. ZDM-Mathematics Education, 49(3), 411-422. https://doi.org/10.1007/s11858-017-0840-1

Blömeke, S., Gustafsson, J.-E., \& Shavelson, R. J. (2015). Competence viewed as a continuum. Zeitschrift Für Psychologie, 223(1), 3-13. https://doi.org/10.1027/2151-2604/a000194

Brady, P., \& Bowd, A. (2005). Mathematics anxiety, prior experience and confidence to teach mathematics among pre-service education students. Teachers and Teaching: Theory and Practice, 11(1), 37-46. https://doi.org/10.1080/1354060042000337084

Bushman, B. J., \& Baumeister, R. J. (1998). Threatened egotism, narcissism, self-esteem, and direct and displaced aggression: Does self-love or self-hate lead to violence? Journal of Personality and Social Psychology, 75(1), 219-229.

Carver, C. S., Sinclair, S., \& Johnson, S. L. (2010). Authentic and hubristic pride: Differential relations to aspects of goal regulation, affect, and self-control. Journal of Research in Personality, 44(6), 698703. https://doi.org/10.1016/j.jrp.2010.09.004

Clem, A.-L., Rudasill, K. M., Hirvonen, R., Aunola, K., \& Kiuru, N. (2020). The roles of teacher-student relationship quality and self-concept of ability in adolescents' achievement emotions: Temperament as a moderator. European Journal of Psychology of Education. https://doi.org/10.1007/ s10212-020-00473-6

Cooke, A., Jenßen, L., \& Norén, E. (2019). Mathematics initial teacher education programs in Sweden, Germany, and Australia. In G. Hine, S. Blackley, \& A. Cooke (Eds.), Mathematics Education Research: Impacting Practice (Proceedings of the 42nd annual conference of the Mathematics Education Research Group of Australasia). Perth: MERGA.

de Hooge, I. E., Breugelmans, S. M., Wagemans, F. M. A., \& Zeelenberg, M. (2018). The social side of shame: Approach versus withdrawal. Cognition and Emotion, 32(8), 1671-1677. https://doi.org/10. 1080/02699931.2017.1422696

de Hooge, I. E., Zeelenberg, M., \& Breugelmans, S. M. (2011). A functionalist account of shame-induced behaviour. Cognition and Emotion, 25(5), 939-946. https://doi.org/10.1080/02699931.2010.516909

Else-Quest, N. M., Higgins, A., Allison, C., \& Morton, L. C. (2012). Gender differences in self-conscious emotional experience: A meta-analysis. Psychological Bulletin, 138(5), 947-981. https://doi.org/10. $1037 / \mathrm{a} 0027930$

Eren, A. (2014). Uncovering the links between prospective teachers' personal responsibility, academic optimism, hope, and emotions about teaching: A mediation analysis. Social Psychology of Education, 17, 73-104. https://doi.org/10.1007/s11218-013-9243-5.

Feldman Barrett, L., \& Russell, J. A. (1998). Independence and bipolarity in the structure of current affect. Journal of Personality and Social Psychology, 74(4), 967-984. https://doi.org/10.1037/00223514.74.4.967

Felson, R. B., \& Trudeau, L. (1991). Gender differences in mathematics performance. Social Psychology Quarterly, 54(2), 113-126. 
Frenzel, A. C. (2014). Teacher emotions. In R. Pekrun \& L. Linnenbrink-Garcia (Eds.), International Handbook of Emotions in Education (pp. 494-519). New York: Routledge. https://doi.org/10.1080/ 02667363.2014.994350.

Frenzel, A. C., Becker-Kurz, B., Pekrun, R., \& Goetz, T. (2015). Teaching this class drives me nuts!Examining the person and context specificity of teacher emotions. PLOS ONE, 10(6), 1-15. https:// doi.org/10.1371/journal.pone.0129630

Frenzel, A. C., Becker-Kurz, B., Pekrun, R., Goetz, T., \& Lüdtke, O. (2018). Emotion transmission in the classroom revisited: A reciprocal effects model of teacher and student enjoyment. Journal of Educational Psychology, 110(5), 628-639.

Frenzel, A. C., Pekrun, R., \& Goetz, T. (2007). Girls and mathematics-A "hopeless" issue? A controlvalue approach to gender differences in emotions towards mathematics. European Journal of Psychology of Education, 22(4), 497-514. https://doi.org/10.1007/BF03173468

Gecas, V. (1982). The self-concept. Annual Review of Sociology, 8, 1-33.

Goetz, T., Frenzel, A. C., Pekrun, R., \& Hall, N. C. (2006). The domain specificity of academic emotional experiences. Journal of Experimental Education, 75(1), 5-29. https://doi.org/10.3200/JEXE. 75.1.5-29

Goldin, G. A. (2014). Perspectives on emotion in mathematical enagegment, learning, and problem solving. In R. Pekrun \& L. Linnenbrink-Garcia (Eds.), International Handbook of Emotions in Education (pp. 391-414). New York: Routledge. https://doi.org/10.1080/02667363.2014.994350.

Gonzalez-DeHass, A. R., Furner, J. M., Vásquez-Colina, M. D., \& Morris, J. D. (2017). Pre-service elementary teachers' achievement goals and their relationship to math anxiety. Learning and Individual Differences, 60(September), 40-45. https://doi.org/10.1016/j.lindif.2017.10.002

Gunderson, E. A., Ramirez, G., Levine, S. C., \& Beilock, S. L. (2012). The role of parents and teachers in the development of gender-related math attitudes. Sex Roles, 66(3-4), 153-166. https://doi.org/10. 1007/s11199-011-9996-2

Gürel, Ç., Brummelman, E., Sedikides, C., \& Overbeek, G. (2020). Better than my past self: Temporal comparison raises children's pride without triggering superiority goals. Journal of Experimental Psychology: General, 149(8), 1554-1566. https://doi.org/10.1037/xge0000733.

Hu, L. T., \& Bentler, P. M. (1999). Cutoff criteria for fit indexes in covariance structure analysis: Conventional criteria versus new alternatives. Structural Equation Modeling, 6(1), 1-55. https://doi.org/10. 1080/10705519909540118

Jackson, C. D., \& Leffingwell, R. J. (1999). The role of instructions in creating math anxiety in students from kindergarten through college. The Mathematics Teacher, 92(7), 583-586. https://doi.org/10. 2307/27971118

Jenßen, L. (2020a). PriMa-Q: Pride in mathematics questionnaire. Humboldt-Universität zu Berlin.

Jenßen, L. (2020b). SHAME-Q: Shame in mathematics questionnaire. Humboldt-Universität zu Berlin.

Jenßen, L., Eid, M., Szczesny, M., Eilerts, K., \& Blömeke, S. (2021a). Development of early childhood teachers' knowledge and emotions in mathematics during transition form teacher training to practice. Journal of Educational Psychology. https://doi.org/10.1037/edu0000518.

Jenßen, L., Möller, R., \& Roesken-Winter, B. (2021b). Shame: A significant emotion in preservice primary school teachers' mathematics education. Paper presented at the 14th International Congress on Mathematical Education (ICME), Shanghai.

Kurtz-Costes, B. E., \& Schneider, W. (1994). Self-concept, attributional beliefs, and school achievement: A longitudinal analysis. Contemporary Educational Psychology, 19, 199-216.

Lewis, M. (2003). The role of the self in shame. Social Research, 70(4), 1181-1204.

Lewis, M., Alessandri, S. M., \& Sullivan, M. W. (1992). Differences in shame and pride as a function of children's gender and task difficulty. Child Development, 63(3), 630-638.

Lewis, M., Sullivan, M. W., Stanger, C., \& Weiss, M. (1989). Self development and self-conscious emotions. Child Development, 60(1), 146-156. https://doi.org/10.1111/j.1467-8624.1989.tb02704.x

Lindberg, S. M., Hyde, J. S., Petersen, J. L., \& Linn, M. C. (2010). New trends in gender and mathematics performance: A meta-analysis. Psychological Bulletin, 136(6), 1123-1135. https://doi.org/10. $1037 / \mathrm{a} 0021276$

Liu, C., Yuan, L., Chen, C., \& Yu, G. (2016). Authentic and hubristic pride as assessed by self, friends, and strangers. Social Psychological and Personality Science, 7(7), 690-696. https://doi.org/10.1177/ 1948550616649240

Lohbeck, A., Grube, D., \& Moschner, B. (2017). Academic self-concept and causal attributions for success and failure amongst elementary school children. International Journal of Early Years Education, 25(2), 190-203. https://doi.org/10.1080/09669760.2017.1301806 
Mainhard, T., Oudman, S., Hornstra, L., Bosker, R. J., \& Goetz, T. (2018). Student emotions in class: The relative importance of teachers and their interpersonal relations with students. Learning and Instruction, 53, 109-119. https://doi.org/10.1016/j.learninstruc.2017.07.011

Marbán, J. M., Palacios, A., \& Maroto, A. (2020). Enjoyment of teaching mathematics among pre-service teachers. Mathematics Education Research Journal. https://doi.org/10.1007/s13394-020-00341-y

Marsh, H. W. (1990). The structure of academic self-concept: The Marsh/Shavelson model. Journal of Educational Psychology, 82(4), 623-636.

Muthén, L., \& Muthén, B. (2017). Mplus user's guide (8th Ed.). Los Angeles: Muthén \& Muthén. https:// doi.org/10.1111/j.1600-0447.2011.01711.x.

Oades-Sese, G. V., Matthews, T. A., \& Lewis, M. (2014). Shame and pride and their effects on student achievement. In R. Pekrun \& L. L. Garcia (Eds.), International handbook of emotions in education (pp. 246-264). New York, London: Routledge. https://doi.org/10.1080/02667363.2014.994350.

Olson, A. M., \& Stoehr, K. J. (2019). From numbers to narratives: Preservice teachers experiences' with mathematics anxiety and mathematics teaching anxiety. School Science and Mathematics, 119(February 2018), 72-82. https://doi.org/10.1111/ssm.12320.

Orth, U., Robins, R. W., \& Soto, C. J. (2010). Tracking the trajectory of shame, guilt, and pride across the life span. Journal of Personality and Social Psychology, 99(6), 1061-1071. https://doi.org/10.1037/ a0021342

Panagi, D. (2013). Shame in mathematics: Turning it on its head. Lambert Academic Publishing.

Pekrun, R., \& Perry, R. P. (2014). Control-value theory of achievement emotions. In R. Pekrun \& L. Linnenbrink-Garcia (Eds.), International Handbook of Emotions in Education (pp. 120-141). New York: Routledge. https://doi.org/10.1080/02667363.2014.994350.

Pulford, B. D., Woodward, B., \& Taylor, E. (2018). Do social comparisons in academic settings relate to gender and academic self-confidence? Social Psychology of Education, 21(3), 677-690. https://doi. org/10.1007/s11218-018-9434-1

Rhemtulla, M., Brosseau-Liard, P. É., \& Savalei, V. (2012). When can categorical variables be treated as continuous? A comparison of robust continuous and categorical SEM estimation methods under suboptimal conditions. Psychological Methods, 17(3), 354-373. https://doi.org/10.1037/a0029315

Roesken, B., Hannula, M. S., \& Pehkonen, E. (2011). Dimensions of students' views of themselves as learners of mathematics. ZDM-International Journal on Mathematics Education, 43(4), 497-506. https://doi.org/10.1007/s11858-011-0315-8

Russell, D., \& McAuley, E. (1986). Causal attributions, causal dimensions, and affective reactions to success and failure. Journal of Personality and Social Psychology, 50(6), 1174-1185.

Ryckman, D. B., \& Peckham, P. D. (1987). Gender differences in attributions for success and failure. Journal of Early Adolescence, 7(1), 47-63.

Rytkönen, K., Aunola, K., \& Nurmi, J. E. (2007). Do parents' causal attributions predict the accuracy and bias in their children's self-concept of maths ability? A Longitudinal Study. Educational Psychology, 27(6), 771-788. https://doi.org/10.1080/01443410701309316

Smith, R. H., Webster, J. M., Parrott, W. G., \& Eyre, H. L. (2002). The role of public exposure in moral and nonmoral shame and guilt. Journal of Personality and Social Psychology, 83(1), 138-159. https://doi.org/10.1037/0022-3514.83.1.138

Stipek, D., \& Gralinski, J. H. (1991). Gender differences in children's achievement-related beliefs and emotional responses to success and failure in mathematics. Journal of Educational Psychology, 83(3), 361-371.

Tangney, J. P. (1999). The self-conscious emotions: Shame, guilt, embarrassment and pride. In T. Dalgleish \& M. J. Power (Eds.), Handbook of Cognition and Emotion (pp. 541-568). John Wiley \& Sons.

Tangney, J. P., Wagner, P., Fletcher, C., \& Gramzow, R. (1992). Shamed into anger? The relation of shame and guilt to anger and self-reported aggression. Journal of Personality and Social Psychology, 62(4), 669-675. https://doi.org/10.1037/0022-3514.62.4.669

Timoštšuk, I., \& Ugaste, A. (2012). The role of emotions in student teachers' professional identity. European Journal of Teacher Education, 35(4), 421-433. https://doi.org/10.1080/02619768.2012. 662637

Tracy, J. L., Cheng, J. T., Robins, R. W., \& Trzesniewski, K. H. (2009). Authentic and hubristic pride: The affective core of self-esteem and narcissism. Self and Identity, 8(2-3), 196-213. https://doi.org/ $10.1080 / 15298860802505053$ 
Tracy, J. L., \& Prehn, C. (2012). Arrogant or self-confident? The use of contextual knowledge to differentiate hubristic and authentic pride from a single nonverbal expression. Cognition and Emotion, 26(1), 14-24. https://doi.org/10.1080/02699931.2011.561298

Tracy, J. L., \& Robins, R. W. (2004). Putting the self into self-conscious emotions: A theoretical model. Psychological Inquiry, 15(2), 103-125. https://doi.org/10.1207/s15327965pli1502

Tracy, J. L., \& Robins, R. W. (2006). Appraisal antecedents of shame and guilt: Support for a theoretical model. Personality and Social Psychology Bulletin, 32(10), 1339-1351. https://doi.org/10.1177/ 0146167206290212

Tracy, J. L., \& Robins, R. W. (2007). The psychological structure of pride: A tale of two facets. Journal of Personality and Social Psychology, 92(3), 506-525. https://doi.org/10.1037/0022-3514.92.3.506

Tracy, J. L., \& Robins, R. W. (2014). Conceptual and empirical strengths of the authentic/hubristic model of pride. Emotion, 14(1), 33-37. https://doi.org/10.1037/a0034490

Turner, J. E., \& Schallert, D. L. (2001). Expectancy-value relationships of shame reactions and shame resiliency. Journal of Educational Psychology, 93(2), 320-329.

van Osch, Y., Zeelenberg, M., \& Breugelmans, S. M. (2018). The self and others in the experience of pride. Cognition and Emotion, 32(2), 404-413. https://doi.org/10.1080/02699931.2017.1290586

Velotti, P., Garofalo, C., Bottazzi, F., \& Caretti, V. (2017). Faces of shame: Implications for self-esteem, emotion regulation, aggression, and well-being. Journal of Psychology, 151(2), 171-184. https:// doi.org/10.1080/00223980.2016.1248809

Weidman, A. C., Tracy, J. L., \& Elliot, A. J. (2016). The benefits of following your pride: Authentic pride promotes achievement. Journal of Personality, 84(5), 607-622. https://doi.org/10.1111/jopy.12184

Weiner, B. (1986). An attributional theory of motivation and emotion. Springer Verlag.

Williams, L. A., \& DeSteno, D. (2008). Pride and perseverance: The motivational role of pride. Journal of Personality and Social Psychology, 94(6), 1007-1017. https://doi.org/10.1037/0022-3514.94.6. 1007

Wubben, M. J. J., de Cremer, D., \& van Dijk, E. (2012). Is pride a prosocial emotion? Interpersonal effects of authentic and hubristic pride. Cognition and Emotion, 26(6), 1084-1097. https://doi.org/ 10.1080/02699931.2011.646956

Zembylas, M. (2003). Emotions and teacher identity: A poststructural perspective. Teachers and Teaching: Theory and Practice, 9(3), 213-238. https://doi.org/10.1080/1354060032000116611

Publisher's Note Springer Nature remains neutral with regard to jurisdictional claims in published maps and institutional affiliations.

Dr. Lars Jenßen is research fellow at the Department of Educational Research at Humboldt-Universität zu Berlin, Germany. He received his diploma in Psychology and his PhD in Educational Science. His research focusses on pedagogical professionals' competence in mathematics, especially on pre- and inservice teachers' emotions in mathematics, for example anxiety, enjoyment, pride and shame. 